\section{Early Migrants}

L. Lawrence Beckie, Bladworth, Sask.

The birds have been rushing in during this warm weather (April 14). One of the rarities of the season is the migration of hawks in such large numbers. From April 8 to April 13 there were quite a few each day. The biggest day was April 12 - Roughlegged Hawks were circling their way north in bunches of four at a time.

On the aftrenoon of Sunday, April 11, I had the privilege of observing three migrating Bald Eagles. They went over our farm, and the one adult (white head) flew quite low over our house. Whereas all the hawks and crows migrate in a northwesterly direction, the Bald Eagle came direct on a south to north flight. I noticed particularly how the neck and head extended much longer than the Golden Eagle (which I also saw Sunday, sitting on a post.)

Two of the eagles flew together and the other one flew through about half an hour earlier. I didn't know what the first one was, because it didn't resemble any hawk, but by the build of the adult I knew it too was an eagle. This is the first Bald Eagle I've seen.

Some migrating dates I have are:

Horned Lark - First migrating wave, February 15.

Common Redpolls - Unusual number of flocks around all winter. Some still here.

Tree Sparrow - March 20; first main flock, April 8.

American Rough-legged Hawk March 17 and 19; pairs, March 23.

Crow - March 21.

Lapland Longspur - April 11, first main flock.

Sparrow Hawk - April 5.

Mountain Bluebird - April 7.

Marsh Hawk - April 7.

Canada Goose (large ones) April 8 to 21. Landed on our farm. Western or Honkers.

Red-tailed Hawk - April 7, 8. Quite a few.

Killdeer - April 8.

Mallard and Pintail - April 8.
Junco and Robin - April 8.

Sandhill Cranes - April 11 - 12.

Bald Eagle - April 11.

Red-winged Blackbird - April 12.

Cooper's Hawk - April 12.

Sharp-shinned Hawk - April 12.

Short-eared Owl - April 13.

\section{Old Man's Garden}

Your editor has had the privilege of reading one of the most interesting books, dealing with the wild flowers of the foothills of Alberta and the adjacent prairie, that has come his way. It is called "Old Man's Garden" and was written by Annora Brown, of Fort McLeod, Alberta, where her family has lived since 1885 , when her father, wearing the red coat of the N.W.M.P., arrived from London, England. The many illustrations of the flowers, most of which are found on the prairie were most artistically drawn by the author.

Most flower books and flower guides are for reference purposes only. One would not think of reading them from cover to cover. Not so this book; every page is a thrill and enjoyment, which quickly carries the reader to the next.

The Old Man is the mythical Indian, Wi-suk-i-tshak, part sun, part god, part man. Old Man created the world. "At first the world was bleak and bare, high walls of grey rock and wastes of desert sand. But Old Man covered them with grass, and with flowers and trees. He put birds in the sky and animals on the land. He made Man and taught him to live with the aid of flowers and animals."

There is an Indian legend, or an explorer's opinion, or a pioneer's version about the prevalence, the beauty and the medicinal or other uses of nearly every flower. If you are interested in our wild flowers and the folklore connected with them, don't miss it!

The book has just been published this year by J. M. Dent and Sons, Aldine House, 1300 Robson Street, Vancouver 5, B.C. The price is $\$ 3.75$. 